\title{
Organizational Hindrances to the Retention of Older Healthcare Workers'
}

I Robin Jonsson

PhD Student at the Department of Sociology and Work Science, University of Gothenburg ${ }^{2}$

1 Agneta Lindegård

Associate Professor at the Institute of Stress Medicine, Gothenburg, Sweden

I Lisa Björk

PhD, Researcher at the Institute of Stress Medicine, Gothenburg, Sweden

\section{Kerstin Nilsson}

Professor at the Department of Health Sciences, Kristianstad University, Sweden \& Associate Professor at the Division of Occupational and Environmental Medicine, Lund University, Sweden

\begin{abstract}
The Swedish healthcare sector is currently experiencing recruitment difficulties combined with increasing demand for healthcare services. This study accordingly seeks knowledge of the obstacles to and opportunities for retaining older employees in the Swedish healthcare sector. Results of interviews with line managers and human resource $(H R)$ partners indicate that the informants have positive attitudes toward older healthcare workers in general, particularly acknowledging their contributions based on long experience and skill. However, line managers' high workload, the absence of age-management strategies, and universal HR policies not conducive to older workers' individual needs are considered obstacles to retention on an organizational level. To retain older healthcare workers and maintain their ability and motivation, the healthcare sector and especially HR strategies need to be more proactive in addressing these issues, and formalized policies are required in order to benefit from the potential labor reserve that older employees constitute.
\end{abstract}

\section{KEYWORDS}

Age management / Line managers / HRM / Swedish healthcare / Active aging policy / Aging workforce / Retirement

\section{Introduction}

ountries across Europe are currently facing various challenges caused by aging populations. Social security systems are being adapted to provide for increasing numbers of retirees, healthcare systems are being transformed to meet the multifaceted needs of the elderly, and high retirement rates are creating labor shortages in certain sectors. These developments are greatly affecting European labor markets and have

\footnotetext{
${ }^{1}$ You can find this text and its DOI at https://tidsskrift.dk/njwls/index.

${ }^{2}$ Corresponding author: Robin Jonsson, Faculty of Social Sciences, Department of Sociology and Work Science, University of Gothenburg. E-mail: Robin.Jonsson@gu.se.
} 
been addressed in the European Union (EU) 2020 Agenda, with the goal of increasing employment rates among 20- to 64-year-olds in all Member States from 71\% in 2018 to $75 \%$ in 2020 (Eurostat 2018).

The Nordic countries are well positioned and have already reached the EU goal as a result of historical efforts to foster high employment rates through active labor market policies targeting men and women, work environment legislation, pension reforms, social security reforms, and actions to combat discrimination and negative attitudes toward older workers (Halvorsen et al. 2013). In Sweden, for example, the pension system has been adjusted so that additional years of labor market participation will result in increasing annual pensions (Kruse 2010). However, the conditions for a prolonged working life still vary between occupational groups (Kadefors et al. 2018a, 2018b), and the likelihood of continuing work after age 65 is higher for men than women, for the highly educated than the low-skilled, and for the self-employed than employees (Kadefors et al. 2017; Nilsson et al. 2016). A number of reports and literature reviews have noted the association between unfavorable working environment, poor health, and labor market exit (Robroek et al. 2013), identifying human service occupations as particularly vulnerable (AMV 2012). A study of labor market exit among 55 to 64-year-olds in the 40 largest professions in Sweden found that older nurse auxiliaries and personal assistants spent more days on sickness and unemployment benefits than the average for these professions (Nilsson et al. 2016).

The healthcare systems in most countries face multiple challenges associated with aging workforces, and long-term forecasts identify a future need for healthcare professionals in the Nordic countries (Nordic Council of Ministers 2014). In Sweden, 50,000 new employees yearly will be needed up to 2026 to achieve increasing production levels and to compensate for retirements. Extended working lives for existing employees have been proposed as one way to address current and future recruitment needs (SKL 2018). Public-sector organizations can act as role models, setting good examples for others to follow. Despite overarching ideas and strategies concerning extended working lives, the sector's priorities and its capability to manage and retain healthcare workers are still uncharted. The objective of this interview study with line managers and their HR partners is accordingly to learn about the obstacles to and opportunities for retaining older employees in the Swedish healthcare sector.

\section{Background}

The proportion of older workers in the European labor market is steadily increasing, and among 55 to 64-year-olds, the employment rate in the EU rose from $38 \%$ in 2002 to $58 \%$ in 2018 (Eurostat 2018). However, this increase is probably not related to European employers' active measures to recruit or retain older workers, since research indicates that such measures are few or lacking (cf. Conen et al. 2012; Fuertes et al. 2013; Jensen \& Møberg 2012).

Employers' measures for older employees are often included in the term 'age management', implying an explicit focus on age in human resource (HR) policies (Naegele \& Walker 2006). Age management entails balancing the interests and needs of different age groups in an organization, and enabling older workers to maintain their work ability and motivation through various work accommodations (Bal et al. 2015; Brooke \&

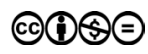


Taylor 2005; Grima 2011; Hasselhorn \& Apt 2015; Naegele \& Walker 2006). Through age-conscious HR policies, employers can offer work accommodations that maintain the functions of older workers (Fabisiak \& Prokurat 2012; Fuertes et al. 2013; Ilmarinen 2006), corresponding to potential motivational changes over the life course (Carstensen 1995; Kanfer \& Ackerman 2004). To be successful, age-management initiatives must be adapted to the complex decision-making process that employees use before retirement, recognizing the importance of individual differences (Fridriksson et al. 2017; Nilsson 2016; Nilsson et al. 2011; Oakman \& Wells 2016) and that top-management support can be critical for successfully managing diversity-including of age-at the workplace level (Kossek et al. 2006).

The incentives for organizations to hire and retain older workers can be understood in light of social exchange theory, according to which the employee contributes to the organization in various ways, and the employer offers various rewards for these efforts (Blau 1964; Jonsson 2007). For example, older workers can contribute their labor power, experience, and specific skills, in return receiving remuneration from the organization in terms of income, benefits, and access to social networks. From an employer perspective, Conen et al. (2011) presented two reasons for organizations to retain and recruit older workers: the business-cycle hypothesis emphasizes the employers' interest in avoiding labor shortages over time; the human-capital hypothesis stresses that older workers can be desirable to employers for their experience, specific skills, and contributions to ensure knowledge transfer to younger employees (Fabisiak \& Prokurat 2012; Fuertes et al. 2013; Nilsson \& Nilsson 2017).

Push factors discouraging older workers from remaining in working life include poor job quality, poor social climate, and physically demanding work tasks (Anxo et al. 2014). General cultural stereotypes about work and aging may hinder older people from finding new jobs late in working life (Kadefors \& Hanse 2012), and negative attitudes and 'ageism' among employers can lead to discrimination against older employees (Furunes \& Mykletun 2007; Harris et al. 2017). Pull factors, such as generous pension and tax schemes, induce older people to leave work. Women generally have poorer retirement benefits, resulting from lower incomes, more extended parental leave, and part-time jobs. In Sweden, it is in female-dominated occupations with low education and income levels that the proportion of 55 to 64-year-olds has increased the most (Nilsson et al. 2016). As financial incentives can be insufficient to compensate for poor health or lack of motivation, prior researchers have advocated improving the work environment and workplace-level adaptations to facilitate older workers' employment (Albin et al. 2017; Fridriksson et al. 2017; Hasselhorn \& Apt 2015).

In the swAge model, Nilsson (2016) connects four main considerations people make before deciding to stay in or withdraw from working life to measures that employers can take to retain older workers. The first consideration is about the individual's health relative to physical and psychosocial work demands. To promote working life participation, employers can, for example, provide ergonomic equipment, flexible working hours, and sufficient recovery time. The second consideration is about the employee's economic situation, which employers can improve by ensuring financial security and promoting employability. The third consideration has to do with the individual's perception of social inclusion and participation at work and in private life. Employers can take measures to increase social support at work and involvement in decision-making processes to motivate older employees to stay in employment. The last consideration relates to 
the individual's sense of meaningfulness and opportunities for personal development. Employers can promote creativity and motivation by offering new tasks, vocational training, and learning activities to people who are near or beyond retirement age.

Organizations' ability to be flexible and offer sustainable working conditions are central to managing the aging workforce (Docherty et al. 2008), and first-line managers have a key role in implementing age-management policies in practice, as they are responsible for daily operations, budget, and staff (Leisink \& Knies 2011). Line managers' knowledge, beliefs, and attitudes toward older workers are essential for the age-management activities in an organization (Furunes et al. 2011), so they may need training to develop sufficient knowledge of work and aging (Bal et al. 2015; Ilmarinen \& Rantanen 1999). Scholars suggest that employers' active engagement and measures at the workplace level are both critical to managing older workers and changing retirement behavior (Jensen \& Møberg 2012; Nilsson 2011; Vickerstaff et al. 2003). However, overarching age-management policies do not necessarily ensure actual activities at lower managerial levels (Boehm et al. 2013) where line managers and their HR partners' role is to implement organizational goals in daily practice. Based on the need to mobilize older healthcare employees to tackle labor shortages (SKL 2018), this interview study sets out to examine line managers and their HR partners' experience and to enhance our knowledge of the obstacles to and opportunities for retaining older employees in the Swedish healthcare sector.

\section{Setting}

The informants of this study were recruited from the age-management intervention program ArbetsKraft, undertaken between 2016 and 2018 in the regions of Skåne (site 1) and Gothenburg (site 2). The program gathered managers and HR representatives from six organizations to raise common issues and discuss solutions with input from invited experts and under the leadership of initiated researchers from the program. The objective of the program was to stimulate the participants to take measures to increase older workers' opportunities to work up to and beyond retirement age. To recruit organizations, we approached HR representatives in larger municipalities and regions and asked them to identify departments or units that might be interested in participating in the program. Managers and/or HR representatives of these units were then approached, informed of the intervention program, and invited to participate. Several organizations declined to participate due to lack of time, staff shortages, and lack of interest. All participants from the organization engaged in the intervention program agreed to participate in the follow-up interview study. The present study was conducted at the end of the program but is independent of the intervention itself. In the limitations section, a more comprehensive discussion about plausible bias related to the sample is presented.

\section{Methods}

\section{Informants and data collection}

Six months after the final meeting in the intervention program, between November 2017 and February 2018, eight line managers and $11 \mathrm{HR}$ partners at five elder-care organizations 
and one hospital ward (Table 1) were interviewed face to face, using an interview guide with questions concerning current age-management policies, practices, incentives, and motivations to retain older workers. The elder-care organizations in this study were both nursing homes and homecare centers. All informants signed a formal consent. The average interview lasted 1 hour and 6 minutes, and all interviews were audio-recorded. For consistency, the same interviewer conducted all interviews at times and locations chosen by the participants. All interviews were transcribed verbatim. The original research program was approved by the Regional Ethical Review Board in Lund (Dnr 2013/722).

Table I The participating healthcare organizations and their informants

\begin{tabular}{lclccc}
\hline Site & Organization & Type & Line manager (n) & HR (n) & Total \\
\hline Site I (Skåne) & $\mid$ & Elder care & 3 & $\mid$ & 4 \\
Site I (Skåne) & 2 & Elder care & $\mid$ & 2 & 3 \\
Site I (Skåne) & 3 & Elder care & - & 2 & 2 \\
Site I (Skåne) & 4 & Elder care & - & 2 & 2 \\
Site 2 (Gothenburg) & 5 & Hospital ward & $\mid$ & 3 & 4 \\
Site 2 (Gothenburg) & 6 & Elder care & 3 & $\mid$ & 4 \\
\hline Total & & & 8 & $\mid 1$ & 19 \\
\hline
\end{tabular}

\section{Data analysis}

A qualitative thematic analysis was conducted to identify themes in the data, guided by the recommendations of Braun and Clarke (2006) and Nowell et al. (2017). To assist data management and the coding process, transcripts were transferred into the qualitative analysis software NVivo 11 (QSR International Pty Ltd). Field notes from the intervention program facilitated the development of the interview guide. During the interviews, the interviewer wrote memos, which helped us in structuring ideas and in differentiating and defining potential themes. The transcribed interviews were read and reread to gain better insights into the data. Guided by our research question, our first analytical step started with identifying parts of the interviews concerning the organizational level; the corresponding passages of the transcripts were coded. In the second step, we examined how the codes fitted together to form broader themes. We then summarized the contents of each theme and checked for their coherence, consistency, and uniqueness. For example, the informants described the challenges of (i) making work accommodations, (ii) individual variation in work ability, and (iii) treating everyone equally. Although these three codes to some extent have distinct meanings, they relate to an underlying theme of addressing individual needs via universal solutions. Another example is how the codes (i) top-level lack of interest, (ii) resistance from central HR departments, and (iii) budget restrictions generated the overarching theme age-management under the radar. Illustrative quotations were then selected to illustrate each theme and are presented in the 'Results' section.

\section{Results}

The thematic analysis identified three overarching themes describing the experience of obstacles to and opportunities for retaining older healthcare workers. The informants 
provided several examples of how older employees were valuable, sometimes even indispensable, to their organizations. Older employees often had an important role in introducing younger employees to the work and in providing social support to less experienced colleagues. For example, they could serve as informal or formal mentors to younger colleagues, and at one workplace, mentoring new colleagues was included in the job contracts of older employees. The informants' interest in retaining older healthcare workers was related not only to older workers' valuable experience and competence but also to the general lack of labor at times when line managers are struggling to secure a reliable supply of human resources.

\section{Heavy manager workload reduces the time for strategic planning}

The acute problem of labor shortage was obvious: in all organizations, line managers and HR staff were struggling to minimize turnover and recruit new employees. The labor shortage was related not only to the lack of nurses and auxiliaries but also to some extent to the fact that some employees had left healthcare to take jobs in other areas or to find employment outside Sweden to increase their income. There was consensus among the informants that this situation was a substantial stressor at work:

I know that my colleagues also have a hellish time finding people. We lack people every day! It takes so much time! Are there people in place? Do we have enough people today? This consumes all our time. (Line manager, elder care)

If we could fill all positions, then we would not have to work so much, be stressed, and always live under the uncertainty: Is that person coming in today? (HR partner, elder care)

Advertising positions, interviewing recruits, assessing their skills, confirming prior experience, and discussing wages consumed a substantial amount of the respondents' work time. High levels of sickness-related absence and complicated rehabilitation processes for employees returning to work added to the line managers' workload. In one elder care unit, a specialized recruitment coordinator facilitated the recruitment of new employees for line managers.

A large number of subordinates reduced the managers' ability to monitor and support all employees in their daily work. Another source of stress among the managers was the sometimes challenging task of ensuring service quality while adhering to a strict budget. This dilemma often led to a feeling of inadequacy among the managers:

We have a very slim budget. For example, I need 110 employees, but the budget only allows for 80 employees. So you know every January when you start again that you won't be able to adhere to the budget ... Often I have considered whether or not I should sign the management agreement [for staff liability] if I don't even have sufficient budget to do what I am supposed to do. (Line manager, hospital ward)

The focus on day-to-day problems led to minimal time for strategic planning, including for establishing age-management strategies. The respondents also called for organizational initiatives to reduce administrative work, support recruitment, and create space 
for reflection and strategic planning. One HR partner described the difficulties facing managers and HR staff in prioritizing older workers:

The problem is that we have 15 other things to do. ... There are always pros and cons when selecting a group and saying: "You are our target group now." To some extent it is not wrong to do so, and it gives them energy. The problem is that we do not have any idea how to do it in practice ... You need a mandate and something more to carry it out in practice. (HR partner, elder care)

Another respondent echoed this:

This is a super-super-super important issue [i.e., retaining older workers], but in the position I am in right now, I will probably not prioritize that issue first. There are other [issues] on my table that I feel are more alarming. (HR partner, hospital ward)

From a broader perspective, the informants stressed the importance of increasing the status of healthcare jobs, especially in elder care, to attract people to the sector.

\section{Age-management under the radar}

Explicit age-management strategies were lacking in the participating organizations: only one employer had a specific program targeting older employees. Informants described a general lack of interest at the top-management level that hinders progress and development:

The biggest problem is the lack of interest. That is the biggest obstacle. My experience is that they [i.e., top management] do not want to touch this question. They do not see the potential ... There is so much to gain by keeping older employees. (Line manager, elder care)

The informants cited several examples of how they had made work accommodationssuch as adjusting work schedules, offering new work tasks (e.g., mentoring), and healthpromoting activities - to enhance older employees' motivation and work ability. However, the general picture was that they needed to be provided with more tools to use when negotiating with their employees:

I do not know what I could offer to someone who is 65 for that person to stay, more than saying, "You are entitled to reduced work time." I have no incentives ... I mean, they have the same equipment as everyone else; they have the same support as everyone else; they have the same as everyone else! I have nothing specific [to offer] because you are older. (Line manager, elder care)

In one participating organization, employees lost their employment contracts after the age of 67 years, regardless of whether or not they wanted to continue working. One manager described arguing with the HR department: 
We have challenged the HR department several times: "Look, here are people who want to continue working after 67 years of age. It is possible in other [neighboring] municipalities, and we want this opportunity here also." But then we were told that it was not possible. (Line manager, elder care)

In the absence of age-management strategies and tools, the managers' ability to retain and recruit older workers instead depended on their personal engagement. The informants felt that the responsibility for age management was in their own hands, whether they liked it or not. An HR partner and a line manager both described the importance of managers' taking their own initiatives in managing older employees:

We are a gigantic organization, we are a colossus. There are so many big questions here, I mean big problems, that we are working on all the time. So it is often up to the manager, I believe, that they should solve it somehow. (HR partner, elder care)

And of course, it's a little bit dependent on the line managers, because you have to be able to fight [with top management] since everything is about the budget. (Line manager, elder care)

Both HR partners and managers advocated more involvement, commitment, and guidance via policies from higher organizational levels to prioritize older employees:

To interest line managers [in age management], I think that you have to bring higher managers along. ... Unfortunately, we have many [higher] managers in position who do not care. (Line manager, homecare)

\section{Individual needs-universal solutions}

Most informants raised the fact that physical work-environment hazards have been reduced in healthcare jobs in recent years. Modern technical equipment facilitates the physical aspects of healthcare work, particularly for those with reduced physical capacities. However, older employees have often been exposed to the heavy lifts and nonergonomic postures that characterized healthcare work a few years back:

Those who are older today, approaching retirement age, many of them have worn-out bodies because they experienced a period when there was no technical equipment. They are also very tired-there are a few who want to stay past 65 , but many want to quit earlier. (Line manager, elder care)

Moreover, technical equipment was not always used as intended, sometimes due to time constraints:

If they use the technical equipment and their bodies properly, they will not become worn out. Many do not use these tools because they think it takes too long. (Line manager, elder care) 
Accumulated exposure to physical strain therefore influences the current work ability of many older employees, yet the informants stressed the significant individual variation:

It is very individual. I mean, I have employees who are over sixty, but who have more energy and drive and alertness than a 35-year-old has. (Line manager, elder care)

In the absence of explicit age-management policies, the managers and their HR management (HRM) partners had to rely on generic HR policies that do not consider age:

There is no action plan, there is no explicit strategy ... there is nothing specific for older workers. What we do, we do for everyone! (HR partner, elder care)

Standardized HR policies were considered to contribute to transparency and organizational justice, yet they were viewed as insufficient for meeting the age-related needs of individual employees. HR partners, in particular, thought that individual deals could be essential to motivate older workers. They stressed the importance of having engaged, experienced, and confident managers capable of transcending the norm of universality to create the right conditions for their older employees. Managers must be able to enforce their decisions and handle conflicting interests among different groups of employees:

We still live with the idea that everything should be so damn fair ... I think that the managers might need support to be courageous and make distinctions [between employees], treating older workers according to their needs and the younger workers in another way. (HR partner, elder care)

We [i.e., the HR department] want to see differentiation in salaries so that you can give some extra to those who have been working for a while and are older. Then it is up to the line managers to determine the salary. I think the line managers are often afraid to give much more [money] to talented older employees because they are afraid it might lead to conflicts in the workplace. So they give the same percent raise [in salary] to everyone. (HR partner, hospital ward)

Some informants were also critical of policies as an instrument for coordination. Their experience was that policies are seldom fully implemented due to, for example, lack of time and commitment:

Unfortunately, the policies often exist "on paper" and nowhere else. I mean, there are policies for the work environment, discrimination, and everything. Everyone knows that the policies exist. There are even higher managers who do not care about them [i.e., the policies], and I mean if the higher managers do not care ... those [managers] below won't either. Policies in all their glory, but you have to work hard with them so that they do not end up existing only on paper. (Line manager, elder care)

Another limiting factor was the reduced possibility of adapting general healthcare tasks to individual requests. Care work entails multiple physical, psychological, and emotional demands, and sometimes reducing these demands is just not possible: 
You can only make accommodations to a certain degree.... There are work tasks that need to be done, so if you're going to assist a client in the morning, it can't take three hours for someone to do it, so there is a certain temporary stress there-you never get away from that. (HR partner, hospital ward)

Both managers and HR partners were critical of the idea that a healthcare worker with reduced work ability can be relocated to, for example, administrative work tasks. There was little room for flexible long-term arrangements:

But it is hard to adjust work over a longer period. You adjust work for the employees so that they can return to their original positions. And if they cannot return, it is impossible to adjust more; instead, you have to relocate [the employee] or do something else. That is the reality, because you cannot make up new positions and services that we don't have so that a worker can stay in the organization. (Line manager, elder care)

\section{Discussion}

Population aging and legislative actions to extend working lives are examples of driving forces behind the increasing share of older workers on European labor markets (Axelrad \& Mahoney 2017; Eurostat 2018), contributing to concerns about workplace conditions among governments, employers, and researchers (Fuertes et al. 2013; Ilmarinen 2006; Naegele \& Walker 2006; SOU 2013). Moreover, current and estimated labor shortages in certain sectors on the Nordic labor markets, for example, in the healthcare sector, potentially threaten the ability to provide high-quality services to citizens (Nordic Council of Ministers 2014). Despite official policies and strategies to retain older workers to avoid labor shortages in the Swedish healthcare sector (SKL 2018), the sector's priorities and readiness to retain healthcare workers have been unclear. This interview study examines line managers and their HR partners' experiences of the obstacles to and opportunities for retaining older employees in the Swedish healthcare sector.

The findings of this interview study indicate that older workers were viewed as valuable resources to their organizations, especially in times of staff shortages, contributing experiences and skills and playing a social role by supporting and transferring knowledge to younger colleagues (Conen et al. 2012). This is in line with the human-capital hypothesis (Conen et al. 2011) that one incentive for employers to retain older workers is that they have something unique to offer. These findings are somewhat contrary to the extensive literature on age discrimination in the labor market (Harris et al. 2017). However, studies in the Nordic context also show positive attitudes among employers (Jensen \& Møberg 2012), and a Norwegian study of the hospitality industry (e.g., hotels) showed that underlying prejudice based on traditional stereotypes could be unfavorable for older workers, despite explicit positive attitudes (Furunes \& Mykletun 2007).

From an exchange perspective (Blau 1964; Jonsson 2007), the employers' need for labor is a potential driver of an extended working life that strengthens the bargaining power of older healthcare workers willing to continue working. However, the absence of formalized HRM policies targeting older workers hinders negotiations between employers and older employees. Individual agreements between line managers and healthcare workers before and beyond retirement do exist, but this study found no indications 
of formalized or systematic negotiations. Consequently, the studied healthcare organizations were incapable of fully benefitting from the potential labor reserve that older workers may constitute in times of labor shortages.

Besides positive attitudes among employers, the expansion of modern technical equipment that assists employees with physically demanding work tasks is another facilitating factor. The age-management literature considers such ergonomic facilities important in promoting working life participation (Kooij et al. 2014; Naegele \& Walker 2006), and these are the first things employers consider for mitigating physical decline, according to the swAge model (Nilsson 2016). However, employees' inclination to use this equipment is sometimes related to other work environment factors, such as time constraints and stress, which also need to be considered.

The results also identified several barriers to good age-management practices. The managers found themselves in a difficult situation due to the insufficient supply of nurses and auxiliaries in the labor market. In one way, this supported age-management practices, since it made every single employee valuable (cf. the business-cycle hypothesis, Conen et al. 2011). On the other hand, the managers had to dedicate considerable time to recruitment and to balancing the quantitative and qualitative demands for services against the need for a sound work environment for those performing the services. This also led to problems for line managers offering older employees, for example, reduced working hours, as insufficient substitute labor was available. Budgetary restrictions moreover reduced the managers' ability to offer competitive salaries. The high workloads of the managers themselves restricted their time for strategic planning on issues such as how to improve the work environment for older workers. The fact that first-line managers have gradually been assigned more responsibility for HR activities has been demonstrated, for example, by Holt Larsen and Brewster (2003) and more recently by Corin and Björk (2017). These results are also in line with a Norwegian study showing that organizational constraints such as lack of time, recruitment needs, and budgetary restrictions complicate middle managers' active engagement with their older employees' individual needs (Midtsundstad \& Bogen 2014).

The informants further described the absence of strategies and tools to manage, motivate, and retain older workers: only one of the organizations had age-management policies in place. The absence of organizational-level measures has been addressed in earlier studies (Conen et al. 2011, 2012; Kooij et al. 2014; Nilsson 2018), and weak top-management commitment could be one explanation for why prior age-management interventions have been ineffective (Hilsen \& Midtsundstad 2015; Kossek et al. 2006). The lack of policies acknowledging older workers as a specific group makes HR activities targeting older employees reliant on the personal engagement of individual managers and on deals negotiated on an individual basis. Although managers' motivation and willingness to support older workers are essential in creating the right workplace conditions (Furunes et al. 2011; Jensen \& Møberg 2012; Leisink \& Knies 2011; Nilsson 2017), dependence on first-line managers' personal incentives can lead to arbitrary outcomes. The lack of age-management policies seems to generate passivity among many line managers and HR partners, even though they consider older workers a valuable resource, even though they face large unmet staffing needs, and even though many of their employees wish to work past retirement age (Nordic Council of Ministers 2014; SKL 2018). A recent UK study showed that managers took an age-neutral approach to management and did not see the need to adapt work to accommodate older employees. 
Also, the absence of formal plans to manage the workplace for older workers led managers to assess work capacity on an individual basis (Egdell et al. 2018).

The line managers and their HR partners also said that employees are supposed to carry out work in a similar way, regardless of individual capacities and despite the fact that certain working conditions such as shift work and night shifts can be especially burdensome for older employees. Diminished physical capacity and need for extra recovery time are some ways in which older healthcare workers likely differ from their younger colleagues. Also, work accommodations were described as temporary for those returning from sick leave, strengthening the idea that healthcare jobs are organized around a universal framework. The standard way of working is to treat all healthcare workers alike, regardless of individual differences. Some of the HR partners mentioned that this approach has unintended consequences for the managers' ability to offer certain individuals or groups of individuals particular arrangements, such as adjusted work schedules. Similar results were found in a study conducted in Norwegian municipalities, which showed that collective values about sameness and equality contributed to universal measures and restricted middle managers' ability to manage individual needs assessments (Midtsundstad \& Bogen 2014). HR practices can either be contingent (i.e., taking, e.g, age or sex into account) or universal (i.e., applying generic practices, irrespective of individual characteristics) (Delery \& Doty 1996). Researchers such as Kooij et al. (2010) support the idea that HR practices should be contingent to allow managers to handle diversity in relation to age, and Kossek et al. (2006) have argued that contingent HRM practices such as diversity management may fail without top-management support.

The themes derived from the empirical analysis are related to one another in a 'vicious circle' that reinforces the underlying problem of labor shortage. Figure 1 illustrates how the organizational hindrances are related: (i) the overall labor shortage leads to timeconsuming recruitment activities and administrative work among both managers and HR representatives, contributing to (ii) high workload among line managers. This strained work situation forces the managers to prioritize day-to-day activities over strategic planning. Issues such as how to retain older workers in the organization are paid insufficient attention, and no age-management strategies are developed. In the absence of (iii) agemanagement strategies, managers rely on universal policies, which (iv) do not provide any specific tools for managing the group of older employees. Without such tools, the organization cannot offer ufficient incentives and work accommodations and are thereby incapable of retaining their older workers, in turn exacerbating the (i) labor shortage.

The synergetic effects described in the hypothetical model make it difficult for lower managerial functions to break out of this vicious circle. It is essential that higher-level management and decision-makers support the managers and their HR partners in changing this destructive dynamic. For example, top management could develop age-management policies in dialogue with lower-level managers and allocate resources so that line managers are provided with the tools they need to make age-sensitive work accommodations. Other functions could take over the work tasks associated with recruitment from line managers so that they have more time to be present at the operational level and adapt the work situation to accommodate individual workers' needs. Although employer organizations are dependent on both institutional arrangements (e.g., the pension system and labor market laws) and individual employees' characteristics (e.g., work ability, health status, and motivation), they are nevertheless important actors that can offer specific incentives for the extension of working life.

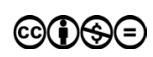


Figure I A hypothetical model showing organizational hindrances to the retention of older healthcare workers.

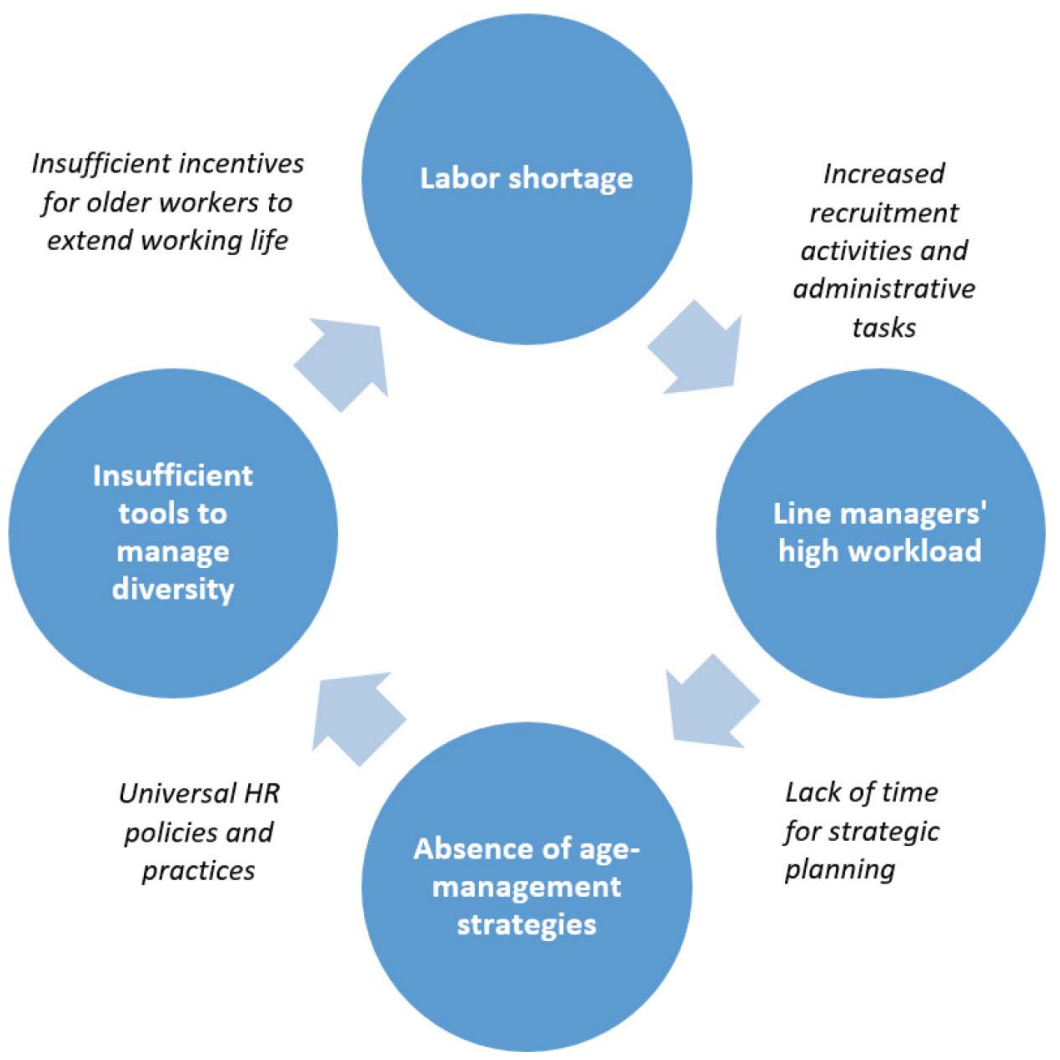

The problems addressed by the informants in both the elder-care organizations and hospital ward were very similar, despite the contextual differences between the organizations in terms of, for example, the variety of professions, job tasks, and location of work. However, this study included only one hospital ward, making any systematic comparison difficult. The lack of age awareness has implications for all the measures employers can take according to the swAge model, such as adjusting work arrangements, increasing financial incentives, and promoting social cohesion and meaningfulness at work (Nilsson 2016). In contrast, the line managers' and HR partners' attitudes and willingness to prolong working life can be considered positive aspects at an organizational level. The lack of organizational commitment and prioritizing evident from the present study are an important explanation for the absence of activities recognizing older healthcare workers. The responsibility transferred to lower managerial functions makes age management arbitrary and reliant on line managers' and their HR partners' experience, attitudes, and available time. Despite positive attitudes toward older workers and the need for personnel, lowerlevel managers can be reluctant to make decisions deviating from organizational policies and practices. Due to the lack of formalized HR policies targeting older workers 
and insufficient time for line managers to put such policies as do exist into practice, healthcare organizations can be unable to benefit from the potential labor reserve that older employees constitute. Developed tools are available for age management-the swAge model, for example-that, in combination with systematic improvements of the work environment, can make working life more sustainable for older workers. To retain and maintain older workers' abilities and motivation, healthcare organizations should not only address short-term problems such as line managers' high workload but also reconsider current policies and practices and be proactive in involving older healthcare workers.

\section{Limitations}

This study mainly focused on the municipal healthcare sector in Sweden. Respondents represented one hospital ward and five elder-care organizations and were recruited using a nonrandom sampling method, using prior contacts and networks in the healthcare sector. Studies with a broader empirical scope must be executed before the identified factors can be shown to be relevant to the entire Swedish healthcare sector. Also, the participants in this study were recruited from an intervention program, making them generally more aware and knowledgeable of aging and age management and preparing them for the upcoming interview study. The participating organizations may have applied to the program because they did not have any age-management strategies in place. However, the main reasons for declining participation among the organizations invited to join the program were time constraints and lack of resources. These potential participants noted that they needed to prioritize daily work and address their most acute problems. In one municipality, eight first-line managers who had initially agreed to participate withdrew just as the study was starting due to reorganization and new budget restrictions. No organization declined participation because it already had well-developed agemanagement strategies.

The organizations declining participation in the intervention program might have been worse off in terms of resources and time. If this were the case, then the organizational-level barriers highlighted here would probably be more pronounced. Another risk is that the representatives of the participating organizations might have had a more positive attitude toward older workers or felt that the inclusion of older employees was more important than did the nonattending organizations. A plausible consequence of this would be failure to locate some of the negative attitudes, such as age discrimination, in the healthcare organizations, thereby overlooking an important factor affecting older workers' continued employment.

\section{Conclusion}

From the perspective of line managers and their HR partners, we have identified facilitating and hindering factors that are important for Swedish healthcare organizations' ability to retain older healthcare workers. The line managers' high workload, the absence of age-management strategies, and universal HR policies not conducive to older workers' individual needs are considered organizational-level obstacles. We argue that these 
barriers may have a synergetic effect, deepening the challenges associated with retaining older healthcare workers. Therefore, to retain older healthcare workers and maintain their abilities and motivation, the healthcare sector and especially HR strategies must be more proactive in addressing these issues, and formalized policies are required in order to benefit from the potential labor reserve older employees constitute.

\section{Conflict of interest}

The authors have no conflict of interest to report.

\section{References}

Albin, M., Liljefrost, E. \& Parmsund, M. (2017). Äldre i arbetslivet [Older people in the workforce], Rapportnummer 2017/00501-1. doi: http://eufonder.se/download/18.5073e01b16020d08de91d06a/1512550487535/\% C3\%84ldre\%20i\%20arbetslivet \%20omv\% C3\% A4rldsanalys.pdf.

AMV (2012). Kunskapsöversikt: Jobba längre- vad vet vi om äldre i arbetslivet? [Research review: Work longer - What do we know about older in workforce?], Rapport 2012:10. doi: https://www.av.se/globalassets/filer/publikationer/kunskapssammanstallningar/jobba-langre-vad-vet-vi-om-aldre-i-arbetslivet-kunskapssammanstallningar-rap-2012-10.pdf.

Anxo, D., Månsson, J. \& Ivarsson, E. (2014). Kunskapssammanställning: sambandet mellan arbetsmiljö och beslutet att lämna arbetskraften. [The association between working environment and the decision to leave workforce] doi: https://www.av.se/globalassets/filer/ publikationer/kunskapssammanstallningar/sambandet-mellan-arbetsmiljo-och-beslutet-att-lamna-arbetskraften-kunskapssammanstallningar-rap-2014-8.

Axelrad, H. \& Mahoney, K. J. (2017). Increasing the Pensionable Age: What Changes Are OECD Countries Making? What Considerations Are Driving Policy? Open Journal of Social Sciences 5: 56. doi: https://doi.org/10.4236/jss.2017.57005.

Bal, P. M., Kooij, D. T. \& Rousseau, D. M. (2015). Aging workers and the employee-employer relationship, Springer. doi: https://doi.org/10.1007/978-3-319-08007-9.

Blau, P. 1964. Exchange and power in social life, Routledge. doi: https://doi. org/10.4324/9780203792643-4.

Boehm, S. A., Schröder, H. \& Kunze, F. (2013). Comparative age management: Theoretical perspectives and practical implications, Sage handbook of aging, work and society: 211-237. doi: https://doi.org/10.4135/9781446269916.n12.

Braun, V. \& Clarke, V. (2006). Using thematic analysis in psychology, Qualitative Research in Psychology 3: 77-101. doi: https://doi.org/10.1191/1478088706qp063oa.

Brooke, L. \& Taylor, P. (2005). Older workers and employment: managing age relations, Ageing and Society 25: 415-429. doi: https://doi.org/10.1017/s0144686x05003466.

Carstensen, L. L. (1995). Evidence for a life-span theory of socioemotional selectivity, Current Directions in Psychological Science 4: 151-156. doi: https://doi.org/10.1111/14678721.ep11512261.

Conen, W. S., Henkens, K. \& Schippers, J. (2012). Employers' attitudes and actions towards the extension of working lives in Europe, International Journal of Manpower 33: 648-665. doi: https://doi.org/10.2139/ssrn.2046974.

Conen, W. S., Henkens, K. \& Schippers, J. J. (2011). Are employers changing their behavior toward older workers? An analysis of employers' surveys 2000-2009, Journal of Aging \& Social Policy 23: 141-158. doi: https://doi.org/10.1080/08959420.2011.551612. 
Corin, L. \& Björk, L. (2017). Job demands and job resources in human service managerial work an external assessment through work content analysis, Old Site of Nordic Journal of Working Life Studies 6: 3-28. doi: https://doi.org/10.19154/njwls.v6i4.5610.

Delery, J. E. \& Doty, D. H. (1996). Modes of theorizing in strategic human resource management: Tests of universalistic, contingency, and configurational performance predictions, Academy of Management Journal 39: 802-835. doi: https://doi.org/10.5465/256713.

Docherty, P., Kira, M. \& Shani, A. R. (2008). Creating sustainable work systems: Developing social sustainability, Routledge. doi: https://doi.org/10.4324/9780203890028.

Egdell, V., Maclean, G., Raeside, R. \& Chen, T. (2018). Age management in the workplace: manager and older worker accounts of policy and practice, Ageing \& Society: 1-21. doi: https://doi.org/10.1017/s0144686x18001307.

Eurostat (2018). Smarter, greener, more inclusive?: indicators to support the Europe 2020 strategy: 2018 edition. Publications Office of the European Union 2018. doi: https://ec.europa.eu/eurostat/documents/3217494/9087772/KS-02-18-728-EN-N.pdf/3f01e3c41c01-4036-bd6a-814dec66c58c.

Fabisiak, J. \& Prokurat, S. (2012). Age management as a tool for the demographic decline in the 21st century: an overview of its characteristics. doi: https://doi.org/10.7341/2012846.

Fridriksson, J. F., Tómasson, K., Midtsundstad, T., Mehlum, I. S., Hilsen, A. I., Nilsson, K. \& Albin, M. (2017). Working environment and work retention, Nordic Council of Ministers. doi: https://doi.org/10.1136/oemed-2018-icohabstracts.119.

Fuertes,V.,Egdell,V.\& McQuaid,R.(2013).Extending working lives: age management in SMEs. Employee Relations 35: 272-293. doi: https://doi.org/10.1108/01425451311320477.

Furunes, T. \& Mykletun, R. J. (2007). Why diversity management fails: Metaphor analyses unveil manager attitudes, International Journal of Hospitality Management 26: 974-990. doi: https://doi.org/10.1080/09585192.2011.559096.

Furunes, T., Mykletun, R. J. \& Solem, P. E. (2011). Age management in the public sector in Norway: exploring managers' decision latitude, The International Journal of Human Resource Management 22: 1232-1247. doi: https://doi.org/10.1080/09585192.2011.5 59096.

Grima, F. (2011). The influence of age management policies on older employee work relationships with their company, The International Journal of Human Resource Management 22: 1312-1332. doi: https://doi.org/10.1080/09585192.2011.559101.

Halvorsen, B., Hansen, O. J. \& Tägtström, J. (2013). Å skape et inkluderende arbeidsmarked Om inkludering av unge, funksjonsnedsatte og seniorer i Norden (et sammendrag), Nordic Council of Ministers. doi: https://doi.org/10.6027/tn2013-537.

Harris, K., Krygsman, S., Waschenko, J. \& Laliberte Rudman, D. (2017). Ageism and the older worker: A scoping review, The Gerontologist 58: e1-e14. doi: https://doi.org/10.1093/ geront/gnw194.

Hasselhorn, H. M. \& Apt, W. (2015). Understanding employment participation of older workers: Creating a knowledge base for future labour market challenges. In: Hans Martin Hasselhorn, W. A. (ed.). doi: https://ec.europa.eu/eip/ageing/file/937/download en?token=zgpij6PB.

Hilsen, A. I. \& Midtsundstad, T. (2015). Domain: Human resource management and interventions. Understanding employment participation of older workers: Creating a knowledge base for future labour market challenges. BMAS/BAuA, Berlin. doi: https://ec.europa.eu/eip/ageing/file/937/download en?token=zgpij6PB.

Holt Larsen, H. \& Brewster, C. (2003). Line management responsibility for HRM: what is happening in Europe? Employee Relations 25: 228-244. doi: https://www.baua.de/EN/ Service/Publications/Cooperation/Gd81.pdf? blob=publicationFile\&v=5.

Ilmarinen, J. (2006). Towards a longer working life. Ageing and the quality of worklife in the European Union. Helsinki. doi: https://doi.org/10.4324/9780203218556 chapter 3. 
Ilmarinen, J. \& Rantanen, J. (1999). Promotion of work ability during ageing, American Journal of Industrial Medicine 36: 21-23. doi: https://doi.org/10.1002/(SICI)10970274(199909) 36:1+<21::AID-AJIM8>3.0.CO;2-S.

Jensen, P. H. \& Møberg, R. J. (2012). Age management in Danish companies: what, how, and how much? Nordic Journal of Working Life Studies 2: 49-66. doi: https://doi. org/10.19154/njwls.v2i3.2363.

Jonsson, D. (2007). Employee Satisfaction, Exchange Paradigms and Community versus Autonomy in Employment Relations. Furåker, B. Håkansson, K. and Karlsson, J. Ch (eds) Flexibility and Stability in Working Life. Houndmills, Basingstoke: Palgrave Macmillan: 155-156. doi: https://doi.org/10.1057/9780230235380.

Kadefors, R. \& Hanse, J. J. (2012). Employers' Attitudes Toward Older Workers and Obstacles and Opportunities for the Older Unemployed to Reenter Working Life. 2012, 2: 19. doi: https://doi.org/10.19154/njwls.v2i3.2362.

Kadefors, R., Nilsson, K., Rylander, L., Östergren, P.-O. \& Albin, M. (2017). Work life length in different occupations: A Swedish population study, Ageing \& Society. doi: https://doi. org/10.1017/S0144686X17000083.

Kadefors, R., Nilsson, K., Rylander, L., Östergren, P.-O. \& Albin, M. (2018a). Occupation, gender and work-life exits: a Swedish population study, Ageing \& Society 38: 13321349. doi: https://doi.org/10.1017/S0144686X17000083.

Kadefors, R., Nilsson, K., Östergren, P.-O., Rylander, L. \& Albin, M. (2018b). Social inequality in working life expectancy in Sweden. Zeitschrift für Gerontologie und Geriatrie. doi: https://doi.org/10.1007/s00391-018-01474-3.

Kanfer, R. \& Ackerman, P. L. (2004). Aging, adult development, and work motivation, Academy of Management Review 29: 440-458. doi: https://doi.org/10.2307/20159053.

Kooij, D. T., Jansen, P. G., Dikkers, J. S. \& De Lange, A. H. (2010). The influence of age on the associations between HR practices and both affective commitment and job satisfaction: A meta-analysis, Journal of Organizational Behavior 31: 1111-1136. doi: https://doi. org/10.1002/job.666.

Kooij, D. T., Jansen, P. G., Dikkers, J. S. \& de Lange, A. H. (2014). Managing aging workers: A mixed methods study on bundles of HR practices for aging workers, The International Journal of Human Resource Management 25: 2192-2212. doi: https://doi.org/10.1080/ 09585192.2013.872169.

Kossek, E. E., Lobel, S. A. \& Brown, J. (2006). Human resource strategies to manage workforce diversity, Handbook of Workplace Diversity 53-74. doi: https://doi. org/10.4135/9781848608092.n3.

Kruse, A. (2010). A stable pension system: The eighth wonder. Population Ageing-A Threat to the Welfare State?: Springer. doi: https://doi.org/10.1007/978-3-642-12612-34.

Leisink, P. L. \& Knies, E. (2011). Line managers' support for older workers, The International Journal of Human Resource Management 22: 1902-1917. doi: https://doi.org/10.1080/ 09585192.2011.573969.

Midtsundstad, T. \& Bogen, H. (2014). Active Aging Policies between Individual Needs and Collective Goods. A Study of Active Aging Policies and Practices in Norway, Nordic Journal of Working Life Studies 4: 139-158. doi: https://doi.org/10.19154/njwls.v4i2.3868.

Naegele, G. \& Walker, A. (2006). A guide to good practice in age management, European Foundation for the Improvement of Living and Working Conditions. doi: http://www. ageingatwork.eu/resources/a-guide-to-good-practice-in-age-management.pdf.

Nilsson, E. \& Nilsson, K. (2017). The Transfer of Knowledge between Younger and Older Employees in the Health and Medical Care: An Intervention Study, Open Journal of Social Sciences 5: 71. doi: https://doi.org/10.4236/jss.2017.57006.

Nilsson, K. (2011). Attitudes of managers and older employees to each other and the effects on the decision to extend working life. In R. Ennals, \& R. H. Salomon (Eds.), Older 
Workers in a Sustainable Society (pp. 147-156). Peter Lang Publishing Group. doi: https://pub.epsilon.slu.se/8731/1/nilsson k 120425.pdf.

Nilsson, K. (2016). Conceptualisation of ageing in relation to factors of importance for extending working life - a review, Scandinavian Journal of Public Health 44: 490-505. doi: https://doi.org/10.1177/1403494816636265.

Nilsson, K. (2017). Active and Healthy Ageing at Work-A Qualitative Study with Employees 55-63 Years and Their Managers, Open Journal of Social Sciences 5: 13. doi: https:// doi.org/10.4236/jss.2017.57002.

Nilsson, K. (2018). Managers' attitudes to their older employees: A cross-sectional study. Work 59: 49-58. doi: https://doi.org/10.3233/wor-172663.

Nilsson, K., Hydbom, A. R. \& Rylander, L. (2011). Factors influencing the decision to extend working life or retire, Scandinavian Journal of Work, Environment \& Health 473-480. doi: https://doi.org/10.5271/sjweh.3181.

Nilsson, K., Östergren, P.-O., Kadefors, R. \& Albin, M. (2016). Has the participation of older employees in the workforce increased? Study of the total Swedish population regarding exit from working life, Scandinavian Journal of Public Health. doi: https://doi. org/10.1177/1403494816637262.

Nordic Council of Ministers (2014). Recruitment and Retention of Health Care Professionals in the Nordic Countries: A Cross-national Analysis, Nordic Council of Ministers. doi: https://doi.org/10.6027/tn2014-554.

Nowell, L. S., Norris, J. M., White, D. E. \& Moules, N. J. (2017). Thematic Analysis: Striving to Meet the Trustworthiness Criteria, International Journal of Qualitative Methods 16: 1609406917733847. doi: https://doi.org/10.1177/1609406917733847.

Oakman, J. \& Wells, Y. (2016). Working longer: What is the relationship between personenvironment fit and retirement intentions? Asia Pacific Journal of Human Resources 54: 207-229. doi: https://doi.org/10.1111/1744-7941.12075.

Robroek, S. J., Schuring, M., Croezen, S., Stattin, M. \& Burdorf, A. (2013). Poor health, unhealthy behaviors, and unfavorable work characteristics influence pathways of exit from paid employment among older workers in Europe: a four year follow-up study, Scand J Work Environ Health 39: 125-33. doi: https://doi.org/10.5271/sjweh.3319.

SKL (2018). Sveriges viktigaste jobb finns i välfärden. Rekryteringsrapport 2018 [Swedish most important work is in the welfare. Recruitment report 2018]. doi: https://webbutik. skl.se/bilder/artiklar/pdf/7585-610-0.pdf? issuusl=ignore.

SOU (2013). Åtgärder för ett längre arbetsliv. Measures for a longer working life]. Swedish Government Official Report: Swedish Pension Age Commission, 2013, SOU, 25, 474. doi: https://www.riksdagen.se/sv/dokument-lagar/dokument/statens-offentliga-utredningar/atgarder-for-ett-langre-arbetsliv H1B325.

Vickerstaff, S., Cox, J. \& Keen, L. (2003). Employers and the management of retirement, Social Policy \& Administration 37: 271-287. doi: https://doi.org/10.1111/1467-9515.00338. 